\title{
Computers in Teaching
}

\section{UK Centre for Physics}

Within the UK, the University Grants Committee and the Computer Board for Universities and Research Councils have been jointly funding the Computers in Teaching Initiative, which covers the whole of higher education, i.e. education beyond the high school. Subject Centres to support potential users opened on 1 April 1989. The Centre for physics is at the University of Surrey in the Department of Physics. The Subject Coordinator is Dr. lan Thompson and the Project Director is Professor Daphne Jackson.

\section{Use of Computers}

The task of our Physics Centre is not so much the enhancement of conventional computer awareness among physics staff, but rather the development of the use of computers in physics teaching as well as in research. Both in the UK and overseas, especially in American universities, physics teachers have been experimenting with computers in undergraduate teaching, but their efforts are not widely known. The Subject Centre for Physics will therefore be used to provide a focus for information on the use of computers at undergraduate and postgraduate level, in the classroom, the laboratory, and project work. One of our first tasks is to make contact with the diverse activities that are already in progress, and by means of electronic mail, news sheets and workshops, to bring information concerning them to a wider range of academics.

\section{Experience in this Department}

During the period 1973-77, the Physics Department at Surrey received support from the National Development Programme in Computer Assisted Learning (CAL) to set up a computational physics teaching laborato$r y$, and to make its use an integral part of the physics degree course.

Since 1987, the Physics Department has moved on from CAL towards a fuller use of computers in undergraduate teaching. There has been particular emphasis on microcomputers for interfacing to physics experiments and the development of facilities for signal and image processing. At postgraduate level, activities range from the application of dedicated microcomputer systems attached to experimental equipment, to advanced numerical modelling and simulations on the CRAY. There is now an interest in developing the advanced undergraduates' and postgraduates' abilities in algebraic computing. Overall the programme encou- rages the teaching of these techniques and instruction in new methods of computing and the new computer architectures that are beginning to be made available.

\section{Contact with Schools}

An important feature of the Surrey Centre, in which it differs from the other Centres, is the contact made with teachers of physics, and with science advisors. This is designed to promote an awareness among academics of curriculum changes and the use of computers in schools, to inform teachers and harmonise school practices with the use of computers in higher education.

\section{External Connection}

There will be extensive cooperation with the Institute of Physics through its publications and subject groups and it is intended to exploit the Department's extensive links with industry and with other universities and laboratories throughout the world in order to exchange experience on methods of teaching using computers.

European colleagues with an interest or expertise in the field are invited to contact the Subject Coordinator, and to indicate if they would like to receive news sheets from the Centre and if they have computer-based teaching material which could be listed in a directory.

D. Jackson

\section{CATEGORY 4a)}

G.C. Alfonso, Genova, 1

O. Entin-Wohlman, Tel Aviv, IL

G.J. Krige, CERN, Geneva, CH

S. Liu, Beijing, PRC

A. Nesis, Freiburg, D

\section{CATEGORY 4c)}

Belgian Physical Society

D. Bolle, Bertem

J. Delwiche, Xhendelesse

E. Dewolf, Kontich

M. Gaigneaux, Brussels

P. Gillis, Mons

M. Huyse, Oud-Heverlee

S. Mathot, Profondeville

F. Poortmans, Lichtaart

R. Vannieuwenhove, Merksem

French Physical Society

J. Appel, Montpellier

M. Averous, Montpellier

J. Bardon, Marseille

G. Bastard, Paris

C. Berthier, St-Martin d'Hères

R. Blanc, Marseille

L. Bonpunt, Talence

P. Bradu, Paris

M. Cambornac, Neuilly-sur-Seine

M. Cauhape, Buc

J. Chappert, Grenoble

E. Charlaix, Lyon

J. Charvolin, Orsay

J. Chatelet, Paris

R. Chery, Villeurbanne

R. Chipaux, St-Genis-Pouilly

R. Deschamps, Paris

R. Dobbertin, Paris

B. Doucot, Claye-Souilly

M. Ducloy, Villetaneuse

\section{New Members of the European Physical Society}

P. Echegut, Meung-sur-Loire

E. Elbaz, Lyon

C. Faure, Villeneuve-St-Georges

R. Fleckinger, Toulouse

A. Fontaine, Orsay

J.P. Ganne, Orsay

J.-C. Gay, Paris

J. Grilhe, Poitiers

F. Guilbault, Nantes

B. Hebral, Grenoble

J. Huck, La Tour de Salvagny

B. Jancovici, Orsay

J.-P. Laheurte, Nice

F. Leclerc, Lille

F. Legay, St-Rémy-les-Chevreuse

R. Lenormand, Rueil Malmaison

D. Lesueur, Palaiseau

E. Locci, Gif-sur-Yvette

M. Maréchal, Bruxelles, B

J. Martineau, Paris

M. Massot, Villeparisis

A. Massoulier, Pessac

G. Montambaux, Bures-sur-Yvette

T. Pierre, Vandœuvre-les-Nancy

G. Pircher, Gif-sur-Yvette

B. Poli, Aussonne

M. Priol, Pace

E. Ressayre, Orsay

F. Roussel, Gif-sur-Yvette

J. Said, Grenoble

J. Sommerid, St-Martin-d'Hères

D. Vignaud, Gif-sur-Yvette

J. Virmont, Palaiseau

R. Walen, Paris

C. Weber, Courbevoie

G. Weill, Fontenay-le-Fleury

J. Winter, Grenoble

J. Wyart, Palaiseau

German Physical Society

D.F. Düchs, Abingdon, UK
W.-D. Klotz, Grenoble, F

B. Lehndorff, Konstanz

J. Meyert-ter-Vehn, Garching

D. Müller, Cologne

R. Pflaum, Konstanz

F. Wagner, Munich

W. Zittel, Munich

Hellenic Physical Society

A. Anagnostopoulos, Thessaloniki

S. Maravelias, Thessaloniki

The Institute of Physics

L.J. Garwin, London

I.G. Hughes, Belfast

M.S. Mousa, Al-Karak, Jordan

K. Sudworth, Ascot

B.S. Wherrett, Edinburgh

Italian Physical Society

L. Trasatti, Frascati

The Netherlands' Physical Society

J.G. Kircz, Amsterdam

F.C. Schüller, Bergen

Physical Section, Union of

Czechoslovak Mathematicians

Physicists and Astronomers

M. Dubovinsky, Spisska Nova Ves

J. Zofka, Prague

Physical Section, Union of Yugoslav Societies of Mathematicians.

Physicists and Astronomers

M. Davidovic, Belgrade

Polish Physical Society

J.A. Ciborowski, Warsaw

A. Ciszewski, Wroclaw

J. Sztucki, Wroclaw
Romanian National Committee for

Physics

F.-D. Buzatu, Bucharest

D. Galeriu, Bucharest

I. Grosu, lasi

N. Rezlescu, lasi

H. Rosu, Magurele

D. Ursu, lasi

Spanish Royal Society of Physics

J. Cervero, Salamanca

A. Hidalgo, Badajoz

F.J. Olivares del Valle, Badajoz

A. Requena, Murcia

J. Zuniga, Murcia

Swedish Physical Society

G.G.E. Björk, Nacka

J. Ejemalm, Uppsala

R. Hellborg, Lund

A. Krozer, Göteborg

B. Mansson, Göteborg

M.P.L. Minnhagen, Umea

L.R. Pendrill, Boras

J. Scheffel, Stockholm

Swiss Physical Society

J.M. Fröhlich, Zurich

\section{CATEGORY 4d}

American Physical Society

J. Noolandi, Mississauga, Ont., Canada

G.A. Sawatzky, Groningen

\section{Associate Members}

Asea Brown Boveri, Heidelberg, FRG

Digital Equipment Corp.

International (Europe),

Petit-Lancy, $\mathrm{CH}$ 